\title{
ANALISIS SEMIOTIKA CITRA POLISI DALAM FILM PENDEK “JONI SOK JAGOAN" DI YOUTUBE
}

\author{
Anisa Diniati, Soraya Ratna Pratiwi \\ Fakultas Industri Kreatif, Institut Teknologi dan Bisnis Kalbis \\ anisa.diniati@kalbis.ac.id
}

Diajukan: 27-03-2018; Direview: 29-05-2018; Diterima: 30-06-2018;

\begin{abstract}
The image of the Indonesian National Police in society is often considered unprofessional. However, in the short film 'Joni Sok Jagoan', the police picture is depicted from a different point of view. The meaning of the message about the police image is the main focus of this research. The purpose of this study is to find out the police image is shown by the short film 'Joni Sok Jagoan' through certain signs or nonverbal messages. This research was conducted by using qualitative approach with semiotic analysis technique from Charles Sanders Peirce. The results show that 'Joni Sok Jagoan'managed to rebuild a positive image of the police. The police are presented as heroes with various tasks that must remain humble in the face of various situations in society. The positive image can also be seen from responsiveness to help others even if that person is degrading profession.
\end{abstract}

Keywords: Police Image, Semiotics Analysis, Short Film, Youtube

\begin{abstract}
Abstrak
Citra Kepolisian Negara Republik Indonesia di tengah masyarakat seringkali dianggap belum maksimal dan tidak profesional. Polisi yang biasanya digambarkan sebagai sosok profesi tidak profesional, film pendek Joni Sok Jagoan menggambarkan citra polisi dari sudut pandang berbeda. Pemaknaan pesan tentang citra polisi yang digambarkan dalam film pendek itulah yang menjadi fokus pada penelitian ini. Tujuan dari penelitian ini adalah untuk mengetahui citra polisi yang ditampilkan oleh film pendek Joni Sok Jagoan melalui tanda-tanda atau pesan nonverbal tertentu. Penelitian ini dilakukan dengan menggunakan pendekatan kualitatif dengan semiotika dari Charles Sanders Peirce sebagai teknik analisisnya. Hasilnya menunjukkan bahwa film pendek tersebut berhasil membangun citra positif polisi kembali, dimana polisi ditampilkan sebagai sosok pahlawan dengan beragam macam tugas yang harus tetap rendah hati dalam menghadapi beragam sikap para pelanggar maupun msyarakat sipil yang membutuhkan bantuan. Citra positif juga terlihat dari sikap tanggap untuk menolong orang lain meskipun orang tersebut sudah merendahkan profesinya.
\end{abstract}

Kata Kunci: Analisis Semiotika, Citra Polisi, Film Pendek, Youtube

\section{PENDAHULUAN}

$\mathrm{C}$ itra Kepolisian Negara Republik Indonesia (Polri) di tengah masyarakat seringkali dianggap belum maksimal dan tidak profesional. Hal yang paling sering dibicarakan masyarakat ialah masalah pelanggaran lalu lintas (tilang). Terdapat sebagian pelanggar lalu lintas memilih untuk menyuap polisi karena beranggapan masalah akan langsung selesai, pun mereka menghindari rumitnya mengurus surat tilang. Selain itu ada pula polisi yang meminta uang kepada para pelanggar lalu lintas agar pelanggar bisa segera pergi dari lokasi pelanggaran tanpa mengikuti prosedur hukum. Website resmi Polri (www.polri.go.id) menyatakan bahwa bila penyuapan ini terbukti maka bisa membuat polisi dan penyuap dihukum penjara karena menyuap polisi/pegawai negeri adalah sebuah perbuatan melanggar hukum .

Dalam ranah Polri sebenarnya sudah ada prosedur bagaimana menghadapi para pelanggar lalu lintas. Polisi yang memberhentikan pelanggar wajib menyapa dengan sopan serta menunjukkan jati diri dengan jelas. Polisi harus menerangkan 
dengan jelas kepada pelanggar apa kesalahan yang terjadi, pasal berapa yang telah dilanggar dan tabel berisi jumlah denda yang harus dibayar oleh pelanggar. Pelanggar dapat memilih untuk menerima kesalahan dan memilih untuk menerima slip biru, kemudian membayar denda di BRI (Bank Rakyat Indonesia) tempat kejadian dan mengambil dokumen yang ditahan di Polsek tempat kejadian, atau menolak kesalahan yang didakwakan dan meminta sidang pengadilan serta menerima slip merah. Pengadilan kemudian yang akan memutuskan apakah pelanggar bersalah atau tidak, dengan mendengarkan keterangan dari polisi bersangkutan dan pelanggar dalam persidangan di kehakiman setempat, pada waktu yang telah ditentukan, biasanya lima sampai sepuluh hari kerja dari tanggal pelanggaran (www.polri.go.id).

Sepanjang hampir satu dasawarsa, tahun 2001 hingga Oktober 2009, hasil jejak pendapat Harian Kompas secara umum menguatkan indikasi terkait citra buruk Polri. "Masyarakat pada kurun hampir sepuluh tahun ini memandang polisi dengan citra buruk berkisar 62 hingga 38\%" (Sutrisno, 2016:7). Kepala Polri Jenderal (Pol) Tito Karnavian mengaku prihatin dengan tingkat kepercayaan publik terhadap institusi kepolisian (Tashandra, 2016).

Di sejumlah survei, tingkat kepercayaan masyarakat terhadap Polri kerap berada di urutan terendah. Untuk bertahan pada era demokrasi, sebuah organisasi harus dipercaya publik. Untuk memperbaiki diri, Polri kini mengkaji faktor penyebab yang membuat rendahnya kepercayaan publik. Dari kajian itu, ditemukan salah satu penyebabnya adalah kinerja Polri yang dianggap masih belum maksimal, terutama dalam halprofesionalisme. Titomemaparkan, di Polri masih banyak penanganan hukum yang berbelit-belit, pemerasan, rekayasa kasus, layanan publik yang masih belum optimal, serta sistem pelaporan berbasis IT yang masih minim.

Kepala Polri Jenderal Tito Karnavian menyebut tingkat kepercayaan masyarakat terhadap institusinya menurun karena tingkat kejahatan yang masih tinggi, profesionalitas polisi, hingga manajemen media massa yang turut mempengaruhi kepercayaan publik terhadap kepolisian.
Menurutnya, berita yang selama ini beredar lebih menyorot perilaku buruk anggota Polri. Tito mengatakan, fakta tersebut diperolehnya dari hasil jajak pendapat sejumlah lembaga survei. Meskipun tidak mempercayai seluruh hasil penelitian itu, Tito mengaku menjadikan data itu sebagai bahan evaluasi kepolisian. Ia mencanangkan perbaikan internal secara menyeluruh untuk memperbaiki citra Polri. (Sofwan, 2016).

Berita yang lebih menyoroti perilaku buruk anggota Polri tentu mempengaruhi citra kepolisian itu sendiri. Perbaikan demi perbaikan kerap dilakukan oleh pihak kepolisian. Meskipun belum maksimal di semua bidang, namun setidaknya survei tahun 2017 menunjukkan kinerja dan citra Polri semakin diapresiasi publik. Hal itu terlihat dari hasil survei Kompas yang dipublikasikan pada Senin (3/7/2017). Sebanyak 46 persen responden menilai kinerja Polri secara umum lebih baik dari tahun lalu. Selain itu, 32,7 persen menilai kinerja Polri sama baik. Namun, sebanyak 10,5 persen responden masih menilai Polri tetap buruk dan 10,3 persen semakin buruk. Dalam surveinya, Kompas meminta penilaian atas kinerja Polri yang berhubungan langsung dengan masyarakat. Terkait penanganan kejahatan di sekitar tempat tinggal, sebanyak 56,5 persen responden menilai, Polri kini lebih baik dan 26,8 persen tetap sama baiknya. Lalu, dalam pengurusan SIM dan STNK, sebanyak 62,2 persen responden menganggap kinerja Polri semakin baik dan 23 persen menilai sama baiknya. Adapun dalam pengaturan lalu lintas, 53 persen responden menilai semakin baik dan 29,7 persen sama baiknya (Kompas.com, 2017).

Prestasi apa yang paling menonjol selama 2017? Mayoritas responden sebesar 43,7 persen menilai prestasi Polripaling menonjol dalam hal penangkapan pengedar narkoba. Lalu, 31,6 persen dalam penanganan terorisme; 10,8 penangkapan penebar teror; 7,4 penangkapan koruptor.

Berdasarkan peningkatan citra polisi yang dilihat dari hasil survei tersebut menunjukkan bahwa tugas Polri memang tidak mudah dan sangat kompleks. Begitu pun untuk memperbaiki citranya. Guna memulihkan citranya dan meningkatan awareness masyarakat terkait pekerjaan atau tugas anggota polisi, Kepolisian Republik Indonesia menyelanggarakan Movie Festival atau kompetisi 
film pendek dengan nama "Police Movie Festival" (PMF). Di setiap tahunnya, mereka memberikan beragam macam tema berbeda yang berkaitan dengan kepolisian.

Kepala Divisi Humas Polri, Brigadir Jenderal Boy Rafli Amar mengatakan kompetisi ini berkaitan dengan Hari Bhayangkara, yang diperingati setiap 1 Juli. Boy menjelaskan bahwa acara ini punya tujuan jangka panjang. Yakni, lebih memasyarakat tugas kepolisian kepada masyarakat. Juga agar masyarakat semakin memahami tugas polisi di masyarakat (Tempo.co).

Pada tahun 2016, penyelenggara PMF memberikan tema yang cukup menarik, yaitu "Hero". Tujuan terselanggaranya Police Movie Festival ini antara lain untuk membuat dan menyuguhkan cerita polisi yang menginsipirasi, mengedukasi dan kisah-kisah heroik yang memberikan semangat perubahan. Adapun landasan dasar mereka mengambil tema tersebut karena baginya polisi bukan sekedar profesi melainkan jalan untuk mengabdi. Menurut pandangan peneliti, seringkali kita lebih mudah melihat titik hitam dalam lembaran kertas putih, dan kata kiasan ini menggambarkan polisi saat ini. Secara realita, polisi memang bukan Superhero, namun perjuangan dedikasi, loyalitas selalu diberikan bukan untuk kepentingan pribadi tetapi untuk kepentingan orang lain. Pengorbanan atas waktu, tenaga dan pikiran tetap tercurahkan untuk menyelesaikan permasalahan masyarakat yang semakin rumit dan pelik. Untuk itulah Polisi diharapkan menjadi HERO yang menampilkan ketauladan bagi siapa saja (www.festivalkreatif. com).

Berkaitan dengan tema yang diberikan oleh pihak penyelanggara, penulis sangat tertarik untuk menganalisis salah satu film pendek yang diproduksi oleh Sebelas Sinema Pictures dengan Judul "Joni Sok Jagoan". Film tersebut berhasil memborong gelar juara. Mereka keluar sebagai juara pertama dengan hadiah 25 juta rupiah, ide cerita terbaik, hingga sutradara terbaik, di mana film terpilih diupload di Youtube. Reza Rahadian sebagai salah satu Juri dalam kompetisi tersebut mengatakan "Joni Sok Jagoan" terpilih sebagai pemenang karena ide dan gagasan sutradara sangat relevan dengan apa yang terjadi saat ini.
"Filemis, pendek, tepat sasaran, ceritanya jelas mau ngapain dari awal sampai akhir, pesan yang mau disampaikan cukup jelas, dan saya melihat reaksi penonton umum juga sangat happy, " kata Reza (Tempo.co).

Sutradara film, Mustafa, mengatakan, pembuatan film ini memakan waktu dua pekan. Ada belasan kru yang terlibat, di luar dari lima pemain. Ia bercerita, ide film ini sebetulnya dari ketertarikan Mustafa pada film Bruce Almighty yang dibintangi Jim Carrey. Dalam film itu, Jim Carrey bertukar peran dengan Tuhan. Menurut Mustafa banyak yang meremehkan polisi selama ini. Ia menganggap citra polisi semakin baik dengan adanya berbagai tayangan program di televisi. Ia memoles temannya menjadi sosok polisi dengan cara mengingat kembali pengalamannya ketika berinteraksi dengan polisi (Tempo.co).

Film Pendek "Joni Sok Jagoan" berdurasi lima menit yang diunggah di Youtube tersebut mengisahkan tentang seorang anak SMA bernama Joni yang harus berhadapan dengan polisi dan saat ia meremehkan kinerja polisi, akhirnya peran mereka tertukar dimana ia harus menghadapi tantangan dengan peran barunya tersebut, namun ia sendiri tidak sanggup melakukannya. Berikut sinopsis singkat yang penulis lansir dari Tempo.co: Joni tidak menyangka bakal berhadapan dengan polisi siang itu. Saat ia tengah asyik buang air kecil di bawah pohon, seorang polisi lalu lintas menghampirinya. Joni kaget dan mengira dirinya salah karena mengencingi pohon. Joni ternyata memarkir motornya di bawah tanda larangan stop. Polisi mau menilang Joni, namun, murid sekolah menengah atas itu justru merendahkan sang polisi. "Ah, polisi cuma bisa tilang," ujar Joni yang diperankan Ahmad Hari Kurniawan. Ia terus mengomel sambil menunjuk ke dada polisi (Adhita Oktavandanu), dan berkata kalau dia jadi polisi maka dia akan lebih baik dari polisi itu. Tiba-tiba, pakaian mereka tertukar. Joni berseragam polisi dan polisi memakai baju putih abu-abu. Helm mereka juga. Joni panik, ia menarik perkataannya. Namun seorang perempuan berteriak meminta tolong. Joni terpaksa mengurusinya.

Karya film ini berhasil memancing tawa 
penonton Police Movie Festival di XXI Epicentrum, Kuningan, Jakarta Selatan, Minggu, 19 Juni 2016. Tidak heran apabila dari 113 film yang sampai ke meja panitia, 10 film pendek dan 3 film animasi masuk ke babak final, Joni Sok Jagoan memborong tiga gelar juara sekaligus.

Hadirnya sosok Joni sebagai pemeran utama dalam film tersebut cukup menarik perhatian penonton. Sosoknya seolah menggambarkan realitas nyata masyarakat yang kerap meremehkan kinerja dan profesionalitas kepolisian yang identik dengan penyuapan bila ingin masalah cepat selesai. Banyak orang memandang demikian karena belum pernah melakukan tugas seperti polisi. Joni yang saat itu seolah "dikutuk" bertukar peran menjadi polisi pun akhirnya terkejut saat seorang wanita meminta tolong karena barangnya dijambret oleh dua pemuda. Joni pun akhirnya ketakutan dan memohon ampun karena tidak mungkin sanggup melakukan pekerjaan polisi (menangkap penjahat). Sikap Joni memberikan pesan moral agar kita tidak merendahkan profesi seseorang bila kita sendiri tidak pernah merasakan di posisinya.

Film pendek ini memiliki cerita yang tak terduga atau tidak kita tebak sebelumnya. Bila penulis bandingkan dengan film pendek lainnya di kompetisi serupa, poin istimewa film ini ialah memiliki moral value atau pesan moral kepada khalayaknya dengan penyajian yang membuat orang sangat terhibur. Dilihat dari adegan pertama hingga terakhir menceritakan bahwa masyarakat harus berpikir bijak serta jangan salah persepsi dalam menilai profesi seseorang, karena dampaknya berpengaruh terhadap citra instansi atau profesi orang tersebut. Hal yang berbeda pun ialah pesan moral yang disampaikan secara implisit (pesan yang tidak dinyatakan secara jelas atau langsung) namun maknanya langsung tepat sasaran serta menghibur.

Realitas yang dihadirkan di film pendek Joni Sok Jagoan tentunya memiliki konstruksi makna tersendiri. Polisi yang biasanya digambarkan sebagai sosok profesi tidak profesional dan tugasnya hanya menilang, film pendek Joni Sok Jagoan menggambarkan citra polisi dari sudut pandang berbeda. Pemaknaan pesan tentang citra polisi yang digambarkan dalam film pendek itulah yang menjadi fokus pada penelitian ini.

\section{LITERATUR DAN METODOLOGI Semiotika}

Semiotika adalah suatu ilmu atau metode analisis untuk mengkaji tanda. Tanda-tanda adalah perangkat yang kita pakai dalam upaya berusaha mencari jalan di dunia ini, di tengah-tengah manusia dan bersama-sama manusia (Sobur, 2009:15). Melalui tanda-tanda, kita mencoba mencari keteraturan di tengah dunia yang tidak beraturan ini, setidaknya agar kita sedikit punya pegangan. "Apa yang dikerjakan oleh semiotika adalah mengajarkan kita bagaimana menguraikan aturan-aturan tersebut dan 'membawanya pada sebuah kesadaran'," ujar Pines (dalam Berger, 2000:14).

Semiosis menurut Charles Sanders Peirce(dalam Littlejohn, 1996:64) ialah "a relationship among a sign, an object, and a meaning (suatu hubungan di antara tanda, objek, dan makna)." Intinya bila kita berbicara mengenai semiotika, kita akan berhubungan dengan suatu tanda. Umberto Eco (dalam Sobur, 2009:18) juga menjelaskan bahwa tanda dapat dipergunakan untuk menyatakan kebenaran, sekaligus juga kebohongan.

\section{Semiotika Charles Sanders Peirce}

Terdapat banyak tokoh yang mengemukakan terkait Semiotika, namun penulis memilih menggunakan Semiotika dari Charles Sanders Peirce atau yang lebih dikenal dengan sebutan Semiotika Peirce. Alasannya karena hasil pemikiran Peirce dan apa yang ia kaji sesuai dengan objek penelitian yang akan penulis kaji disini. Peirce (dalam Sobur, 2009:40-41) terkenal karena teori tandanya. Peirce seringkali mengulang-ulang bahwa secara umum tanda adalah yang mewakili sesuatu bagi seseorang.

Semiotika berangkat dari tiga elemen utama, yang disebutPeirce teorisegitiga makna atautriangle meaning (Kriyantono, 2009:265): a) Tanda adalah sesuatu yang berbentuk fisik yang dapat ditangkap oleh panca indera manusia dan merupakan sesuatu yang merujuk (merepresentasikan) hal lain diluar tanda itu sendiri; b) Acuan Tanda (Object) adalah konteks sosial yang menjadi referensi dari tanda atau sesuatu yang dirujuk tanda. Sobur (2009:4142) menambahkan bahwa berdasarkan objeknya, Peirce membagi tanda atas icon (ikon), index (indeks), dan symbol (simbol). Icon adalah tanda 
yang hubungan antara tanda dan objek atau acuan yang bersifat kemiripan, seperti peta. Indeks adalah tanda yang menunjukkan adanya hubungan alamiah antara tanda dan petanda yang bersifat kausal atau hubungan sebab akibat, seperti asap sebagai tanda adanya api. Sedangkan berdasarkan interpretant, tanda dibagi atas rheme, dicent sign atau dicisign, dan argument; dan c) Pengguna Tanda (Interpretant). Konsep pemikiran dari orang yang menggunakan tanda dan menurunkannya ke suatu makna tertentu atau makna yang ada dalam benak seseorang objek yang dirujuk sebuah tanda.

\section{Citra Polisi}

Citra menurut Pedoman Umum Ejaan Bahasa Indonesia ialah rupa; gambar; atau gambaran. Sedangkan Katz (dalam Ruliana, 2014:224) mengatakan bahwa citra adalah cara pihak lain memandang sebuah perusahaan, seseorang, suatu komite atau suatu aktivitas. Sementara itu Sukatendel (dalam Ruliana, 2014:224) menyatakan bahwa citra adalah kesan, perasaan, gambaran diri publik terhadap perusahaan, kesan yang dengan sengaja diciptakan dari suatu objek, orang, atau organisasi. Jadi, seperti yang diungkapkan Sukatendel, citra itu dengan sengaja perlu diciptakan agar bernilai positif. Citra itu sendiri merupakan suatu aset terpenting dari suatu perusahaan atau organisasi.

\section{Film Pendek}

Undang-undang Nomor 33 Tahun 2009 tentang Perfilman pada Bab 1 Pasal 1 menyebutkan, yang dimaksud dengan film adalah karya seni budaya yang merupakan pranata sosial dan media komunikasi massa yang dibuat berdasarkan kaidah sinematografi dengan atau tanpa suara dan dapat dipertunjukkan (Vera, 2015:91).

Film dibagi menjadi dua, yaitu film pendek dan film panjang. Film pendek sendiri didefinisikan sebagai salah satu bentuk film paling simpel dan paling kompleks. Di awal perkembangannya, film pendek sempat dipopulerkan oleh komedian Charlie Chaplin. Film pendek sendiri tergolong dalam film fiksi yang termasuk sebuah karya animasi yang memiliki durasi tayang tidak lebih dari 60 menit. Selain itu, film pendek bukan merupakan reduksi dari film dengan cerita panjang, atau sebagai wahana pelatihan bagi pemula yang baru masuk ke dunia perfilman. Film pendek memiliki ciri atau karakteristik sendiri yang membuatnya berbeda dengan film cerita panjang, bukan karena sempit dalam pemaknaan atau pembuatannya lebih mudah serta anggaran yang minim. Tapi karena film pendek memberikan ruang gerak ekspresi yang lebih leluasa untuk para pemainnya (International Design School, 2014)

\section{Tanda-tanda non verbal dalam Semiotika}

Identitas dan citra - diri kita di mata orang lain dipengaruhi oleh cara kita berkomunikasi. Penampilan kita (termasuk busana dan gaya rambut) serta perlengkapan lainnya seperti arloji, kacamata, sepatu, dan tas, akan memberi kesan kuat tentang siapa kita (Mulyana dalam Kholifah, 2014:138).

Secara sederhana, tanda nonverbal dapat kita artikan semua tanda yang bukan kata-kata. Menurut Pateda (dalam Sobur, 2009:122), terdapat beberapa cara untuk menggolongkan tandatanda, yaitu: a) Tanda yang ditimbulkan oleh alam yang kemudian diketahui manusia melalui pengalamannya; misalnya, kalau langit sudah mendung menandakan akan turun hujan, dan kalau sudah turun hujan terusmenerus ada alasan untuk timbulnya banjir, dan kalau sudah banjir ada alsasan untuk timbulnya penyakit; b) Tanda yang ditimbulkan oleh binatang; misalnya kalau ada anjing menyalak kemungkinan ada tamu yang memasuki halaman rumah, atau tanda bahwa ada pencuri; dan c) Tanda yang ditimbulkan manusia.

Tanda yang ditimbulkan oleh manusia dapat dibedakan atas yang bersifat verbal dan yang bersifat nonverbal Pateda (dalam Sobur, 2009:122). Yang bersifat verbal adalah tanda-tanda yang digunakan sebagai alat komunikasi yang dihasilkan oleh alat bicara, sedangkan yang nonverbal dapat berupa: (i) tanda yang menggunakan anggota badan, lalu diikuti dengan lambang, misalnya "Mari!"; (ii) suara, misalnya bersiul yang bermakna memanggil seseorang; (iii) tanda yang diciptakan oleh manusia untuk menghemat waktu, tenaga, dan menjaga kerahasiaan, misalnya rambu-rambu lalu lintas, bendera, tiupan terompet; dan (iv) benda-benda yang bermakna kultural dan ritual.

\section{Komunikasi Non verbal}

Kita mempersepsi manusia tidak hanya 
lewat bahasa verbalnya saja seperti bahasanya (halus, kasar, intelektual, mampu berbahasa asing, dan sebagainya), namun juga melalui perilaku nonverbalnya. Pentingnya pesan nonverbal ini misalnya dilukiskan frase, "Bukan apa yang ia katakana, melainkan bagaimana ia mengatakannya." Lewat perilaku nonverbalnya, kita dapat mengetahui suasana emosional seseorang, apakah ia sedang bahagia, bingung, atau sedih. (Mulyana, 2008:342).

Secara sederhana, pesan nonverbal adalah semua isyarat yang bukan kata-kata. Menurut Larry A. Samovar dan Richard E. Potter, komunikasi nonverbal mencakup semua rangsangan (kecuali rangsangan verbal) dalam suatu setting komunikasi, yang dihasilkan oleh individu dan penggunaan lingkungan oleh individu, yang mempunyai nilai pesan potensial bagi pengirim atau penerima. Bersama isyarat verbal dan isyarat kontekstual, pesan nonverbal membantu kita menafsirkan seluruh makna pengalaman komunikasi (Mulyana, 2008:343).

Pada dasarnya, komunikasi nonverbal berfungsi untuk memperkuat pesan verbal itu sendiri. Seperti yang ditelah dipaparkan oleh (Devito, 2011:194) bahwa komunikasi nonverbal dapat menjalankan sejumlah fungsi penting, yaitu untuk menekankan beberapa bagian dari pesan verbal; untuk melengkapi atau memperkuat sikap umum yang dikomunikasi oleh pesan verbal; untuk menunjukkan kontradiksi atau mempertentangkan pesan verbal dengan gerakan nonverbal; untuk mengatur arus pesan verbal; untuk mengulangi atau merumuskan-ulang makna dari pesan verbal; dan terakhir untuk menggantikan pesan verbal.

Bila melihat fungsi dari komunikasi nonverbal tersebut dapat terlihat bahwa antara komunikasi nonverbal melengkapi komunikasi verbal. Secara teoritis komunikasi non verbal dan komunikasi verbal dapat dipisahkan. Namun dalam kenyataannya, kedua jenis komunikasi ini saling jalin menjalin, saling melengkapi dalamkomunikasi yang kita lakukan sehari-hari. Rahmat (2011:285) mengelompokkan pesan-pesan non verbal menjadi lima, yaitu pesan kinesik, proksemik, artifaktual, paralingustik, serta sentuhan dan bau-bauan.

Pesan Kinesik merupakan pesan non verbal yang menggunakan gerakan tubuh yang terdiri dari: a) pesan fasial yang menggunakan air muka untuk menyampaikan makna tertentu. Berbagai penelitian menunjukkan bahwa wajah dapat menyampaikan paling sedikit sepuluh kelompok makna, yaitu kebahagiaan, rasa terkejut, ketakutan, kemarahan, keseduhan, kemuakan, pengecaman, minat, ketakjuban, dan tekad. Leather menyimpulkan penelitian-penelitian tentang wajah sebagai berikut, yaitu wajah mengkomunikasikan penilaian dengan ekspresi senang dan tak senang yang menunjukkan apakah komunikator memandang objek penelitiannya baik atau buruk; wajah mengkomunikasikan berminat atau tak berminat pada orang lain atau lingkungan; wajah mengkomunikasikan intensitas keterlibatan dalam situasi; wajah mengkomunikasikan tingkat pengendalian individu terhadap pernyataan sendiri; dan wajah barangkali mengkomunikasikan adanya atau kurang pengertian.

Pesan kedua dalam pesan kinesik, yaitu b) pesan gestural yang menunjukkan gerakan sebagian anggota badan seperti mata dan tangan untuk mengkomunikasikan makna. Sedangkan pesan ketiga dalam pesan kinesik adalah c) pesan postural yang berkenaan dengan keseluruhan anggota badan. Adapun makna yang disampaikannya adalah: immediacy, yaitu ungkapan kesukaan dan ketidaksukaan terhadap individu yang lain. Postur yang condong ke arah yang di ajak bicara menunjukkan kesukaan dan penilaian positif; power mengungkapkan status yang tinggi pada diri komunikator. Anda dapat membayangkan postur orang yang tinggi hati di depan anda, dan postur orang yang merendah; dan responsiveness, Individu dapat bereaksi secara emosional pada lingkungan secara positif dan negatif. Bila postur anda tidak berubah, anda mengungkapkan sikap yang tidak responsif.

Pesan Proksemik merupakan pesan yang disampaikan melalui pengaturan jarak dan ruang. Umumnya dengan mengatur jarak kita mengungkapkan keakraban kita dengan orang lain. Edward Hall (dalam Littlejohn \& Foss 2014:162) penemu proxemics, mendefinisikan tiga jenis jarak, yaitu ruang karakteristik terbatas terdiri dari benda-benda yang tidak dapat dipindahkan seperti dinding dan kamar; ruang karakteristik semi terbatas meliputi objek yang dapat bergerak seperti furnitur; dan ruang informal adalah daerah pribadi sekitar tubuh yang menjalar dengan tubuh 
seseorang dan menentukan jarak antarpribadi di antara manusia.

Pesan Artifaktual merupakan pesan yang diungkapkan melalui penampilan tubuh, pakaian, dan kosmetik. Walaupun bentuk tubuh relatif menetap, orang sering berperilaku dalam hubungan dengan orang lain sesuai dengan persepsinya tentang tubuhnya (Body Image). Erat kaitannya dengan tubuh ialah upaya kita membentuk citra tubuh dengan pakaian, dan kosmetik.

Pesan Paralinguistik adalah pesan non verbal yang berhubungan dengan cara mengucapkan pesan verbal. Satu pesan verbal yang sama dapat menyampaikan arti yang berbeda bila diucapkan secara berbeda. Pesan ini oleh Dedy Mulyana disebutnya sebagai parabahasa.

Pesan sentuhan dan bau-bauan merupakan alat penerima sentuhan adalah kulit yang mampu menerimadanmembedakanemosiyangdisampaikan orang melalui sentuhan. Sentuhan dengan emosi tertentu dapat mengkomunikasikan: kasih sayang, takut, marah, bercanda, dan tanpa perhatian. Baubauan, terutama yang menyenangkan (wewangian) telah berabad-abad digunakan orang, juga untuk menyampaikan pesan - menandai wilayah mereka, mengidentifikasi keadaan emosional, pencitraan, dan menarik lawan jenis.

\section{Penelitian Terdahulu}

Penelitian terdahulu yang peneliti gunakan adalah penelitian dengan judul Analisis Semiotika Representasi Perilaku Masyarakat Jawa dalam Film Kala (Herwendo, 2014:230). Penelitian tersebut ditulis oleh Rionaldo Herwendo dan dipublikasikan di Jurnal Wacana Volume XIII No.3, Agustus 2014. Penelitian Herwendo memiliki persamaan dengan penelitian ini dari segi topik yang diangkat, yaitu representasi terkait sesuatu yang dikemas dalam bentuk film. Perbedaannya, jurnal ini menggunakan analisis semiotika yang dikemukakan oleh Roland Barthes, di mana Barthes lebih menekankan pada pemaknaan suatu tanda, sedangkan analisis Peirce yang peneliti gunakan lebih menekankan pada interpretasi suatu tanda.

Perbedaan lainnya dilihat dari objek yang diteliti. Pada jurnal ini mereka mengemukakan representasi perilaku masyarakat Jawa pada film Kala dan terlihat pada bagian hasil mereka membandingkan dengan mitos masyarakat Jawa di kehidupan nyata. Sedangkan peneliti sendiri juga sama-sama mengemukakan citra polisi dalam kehidupan nyata yang sering dianggap tidak profesional, namun dalam film pendek Joni Sok Jagoan, citra tersebut justru bisa berubah dengan sudut pandang yang berbeda.

\section{Metodologi Penelitian}

Penelitian ini dilakukan dengan menggunakan pendekatan kualitatif dengan semiotika dari Charles Sanders Peirce sebagai teknik analisisnya. Data diperoleh melalui data primer dan data sekunder. Data primer yang digunakan yaitu film pendek berjudul "Joni Sok Jagoan" karya Sebelas Sinema Pictures yang meraih juara pertama pada lomba Police Movie Festival 2016 yang dimana hasil karyanya di upload di Youtube. Peneliti menganalisis dengan memenggal tiap scene menjadi satu atau beberapa shot (potongan gambar). Data yang diolah berupa kombinasi antara data visual dan data verbal. Sedangkan data sekundernya, peneliti membaca dan mempelajari sejumlah buku, artikel online, serta pustaka hasil penelitian lain yang berkaitan dengan penelitian ini untuk mendukung hasil penelitian.

Adapun yang menjadi fokus dalam penelitian ini adalah komunikasi non verbal yang digunakan dalam film pendek "Joni Sok Jagoan" di Youtube yang terkait dengan citra kepolisian yang meliputi Pesan Kinesik (fasial, gestural, dan postural), Pesan Proksemik, Pesan Artifaktual, dan Pesan Sentuhan, yang selanjutnya diolah dengan konsep segitiga makna Peirce yang diklasifikasikan menjadi tiga bagian yaitu Tanda (Sign), Acuan Tanda (Object), dan Pengguna Tanda (Interpretant).

\section{TEMUAN DAN DISKUSI \\ Analisis Tanda dan Sajian Tanda}

Pembahasan mengenai pesan yang terdapat dalam film pendek "Joni Sok Jagoan" di Youtube menggunakan semiotik Peirce dengan menggunakan tiga tahap yaitu tahap deskripsi jalan cerita, tahap identifikasi dan klasifikasi tanda, dan tahap analisis semiotika berdasarkan teori segitiga makna atau triangle meaning dari Charles Sanders Peirce.

Identifikasi, Klasifikasi, dan Interpretasi Tanda Scene 1 

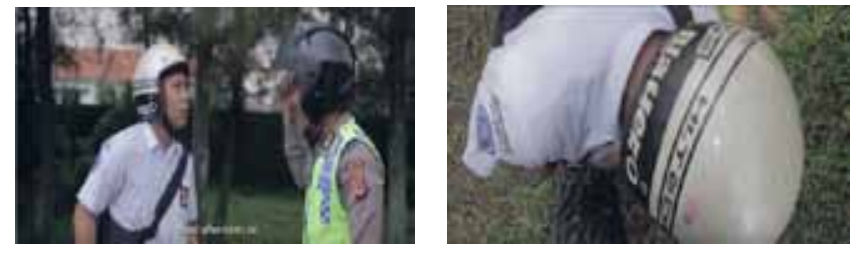

Gambar 1. Scene 1

(Sumber: www.youtube.com)

Pada scene 1, makna tanda non verbal yang ditunjukkan adalah pesan artifaktual yaitu ingin menunjukkan status pada profesi masing-masing dengan menggunakan seragam sebagai ciri khas status mereka. Joni ditampilkan sebagai anak Sekolah Menengah Atas (SMA) dengan mengenakan seragam kemeja putih, logo OSIS (Organisasi Siswa Intra Sekolah) dengan background cokelat, atribut nama sekolah dan lambang sekolah di lengan kanan, serta celana panjang berwarna abu-abu. Sedangkan Polisi ditampilkan menggunakan seragam dinas polisi berwarna cokelat berompi kuning serta helm berwarna hitam.

Barnard (2006:103) mengatakan bahwa fashion, pakaian, dan busana dapat dianggap sebagai salah satu makna yang digunakan oleh kelompok sosial dalam mengomunikasikan identitas mereka sebagai kelompok sosial ke kelompok sosial lainnya. Dari segi pakaian dan atribut yang digunakan sudah menunjukkan bahwa mereka sesuai dengan status atau profesi yang ingin ditampilkan. Namun ada beberapa hal yang perlu menjadi fokus perhatian. Pertama, pada helm Joni tertera stiker berlambangkan bendera Amerika Serikat. Seseorang yang memiliki minat atau menyukai suatu hal, ia cenderung akan menampilkannya melalui simbol-simbol tertentu, begitupun dengan stiker yang menempel di helm Joni. Amerika Serikat sendiri merupakan negara yang menganut federalisme sebagai sistem politiknya dan mereka sudah sejak lama memproklamirkan diri sebagai "the land of the free" atau tanah orang-orang bebas. Maka dapat disimpulkan bahwa meskipun Joni menggunakan seragam SMA sebagai warga Indonesia, ia berusaha menampilkan perilakunya dengan bebas seperti orang barat, seperti buang air kecil sembarangan dan memarkir motor di sepanjang area bersimbol "Dilarang Stop" (Lihat Gambar 2).
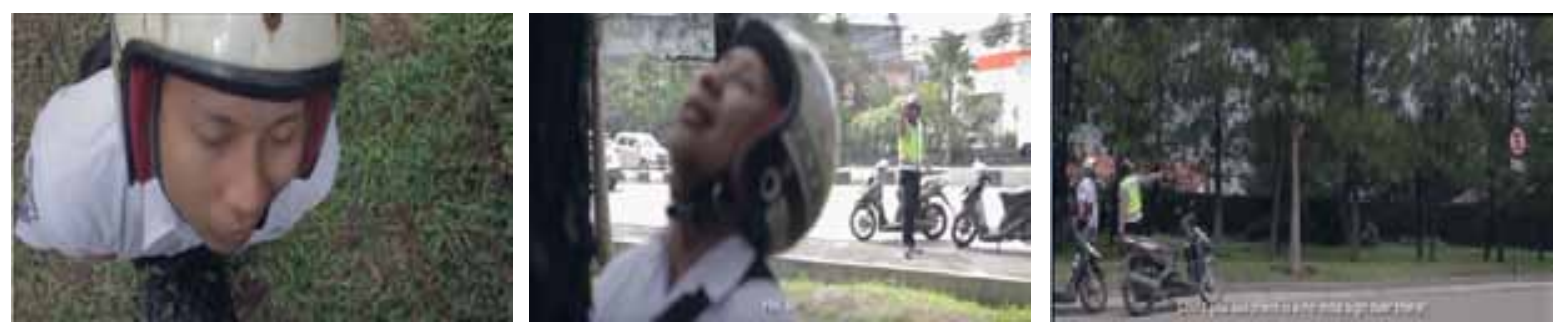

Gambar 2. Pelanggaran yang Dilakukan oleh Joni

(Sumber: www.youtube.com)

Perilaku yang ditampilkan Joni dengan ketidakpatuhannya terhadap rambu lalu lintas serta dengan buang air kecil di tempat umum (pinggir trotoar) seolah menggambarkan fenomena masyarakat secara umum dan anak sekolahan secara khusus. Siapapun yang menggunakan seragam sekolah seharusnya mampu menampilkan bahwa mereka adalah orang yang terdidik, karena anak sekolahan identik dengan orang-orang yang berintelektual tinggi dan tidak seharusnya melanggar peraturan. Seperti yang dikatakan oleh Barnard bahwa pakaian dipandang memiliki suatu fungsi komunikatif di mana busana, pakaian, kostum, dan dandanan adalah bentuk komunikasi artifaktual (artifactual communication). Hal ini dikarenakan fashion, pakaian atau busana menyampaikan pesan-pesan nonverbal. Selain itu, Hudzaifah, dan Dardi (2013:3) mengungkapkan dalam artikelnya bahwa pakaian seragam tidak berarti hanya pakaian sebagai identitas, melainkan bentuk pendisiplinan. Pemakaian seragam sekolah kepada siswa di sekolah bertujuan untuk membuat siswa mudah diarahkan, diatur, dan agar siswa berdisiplin diri.

\section{Identifikasi, Klasifikasi, dan Interpretasi Tanda Scene 2}

Pada scene 2 (Lihat Gambar 3), makna tanda 
non verbal yang ditunjukkan adalah pesan kinesik dan proksemik yaitu ingin menunjukkan profesi atau tupoksi (tugas, pokok, dan fungsi) pihak kepolisian dengan menegur secara sopan pada pihak pelanggar yaitu Joni sebagai anak SMA dengan aturan jarak tertentu antara pihak penegur dengan pihak yang ditegur. Dalam adegan tersebut secara keseluruhan menginterpretasikan pencitraan sosok kepolisian dengan membuat jarak dekat, memberi hormat, menegur secara tegas, menjelaskan kesalahan pihak pelanggar, serta memberi kesan polisi adalah sosok yang sabar saat pihak pelanggar menyepelekan pekerjaannya.
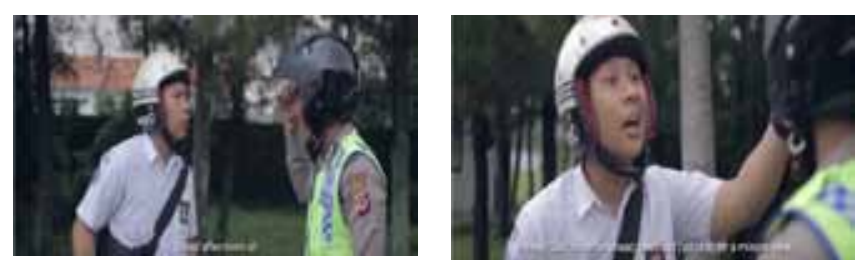

Gambar 3. Scene 2

(Sumber: www.youtube.com)

Pertama, pada pesan proksemik, polisi membuat jarak dengan pelanggar (Joni) kurang lebih $60 \mathrm{~cm}$. Jarak yang mereka bangun termasuk ke dalam komunikasi pribadi, karena jarak 45-120 cm termasuk dalam komunikasi pribadi. Komunikasi pribadiatauantarpribadidisiniterjadi di antara polisi dengan pelanggar. Menurut Devito (2011:253) dalam interaksi antarpribadi kita bereaksi terhadap pihak lain berdasarkan data psikologis, sedangkan dalam perjumpaan tak-pribadi (impersonal) kita menanggapi orang lain berdasarkan data sosiologis. Seperti kita memandang polisi di tengah masyarakat adalah orang yang hebat dan berani karena mampu menangkap penjahat, namun akan berbeda pandangannya saat masuk ke ranah komunikasi pribadi.

Dalam kasus tersebut karena polisi dan Joni sebagai pelanggar masuk ke ranah komunikasi pribadi, maka saling bereaksi berdasarkan data psikologis mereka masing-masing, seperti Joni yang tidak terima saat polisi menyatakan dirinya melanggar rambu dilarang berhenti.

Kedua, pesan kinesik berupa pesan gestural tampak pada polisi. Sebelum menegur dan menjelaskan kesalahan pihak pelanggar, ia menyapa dengan sopan disertakan gerakan tangan memberi hormat terlebih dahulu. Gerakan anggota badan dengan memberi hormat pada pelanggar menunjukkan makna polisi tersebut tetap menghormati lawan bicaranya meskipun ia tahu bahwa orang yang ada di hadapannya adalah orang yang melanggar rambu lalu lintas. Selain itu dalam kepolisian sendiri memang terdapat prosedur penilangan, dimana polisi yang memberhentikan pelanggar wajib menyapa dengan sopan serta menunjukkan jati diri dengan jelas. Polisi harus menerangkan dengan jelas kepada pelanggar apa kesalahan yang terjadi, pasal berapa yang telah dilanggar dan tabel berisi jumlah denda yang harus dibayar oleh pelanggar.

Pesan kinesik selanjutnya dilihat dari pesan fasial dan gestural si pelanggar yang diperankan oleh Joni sebagai anak SMA yang menganggap memberhentikan sepeda motor di area dilarang berhenti bukanlah kesalahan yang fatal karena ia juga terjepit kondisi ingin membuang air kecil. Wajah pelanggar mengkomunikasikan penilaian dengan ekspresi tidak senang seolah menunjukkan lawan bicara adalah seorang musuh. Ekspresi tidak senang ditunjukkan dengan mata melotot dan bicara dengan mengangkat bibir dengan posisi bagian kiri lebih tinggi (sinis). Ketidaksenangannya juga diperkuat dengan pesan postural berupa immediacy dimana pelanggar menunjukkan postur yang condong ke arah polisi dengan cara membusungkan dada ke depan ditambah dengan pesan gestural berupa gerakan tangan yang menunjuk-nunjuk tiang rambu dilarang berhenti.

\section{Identifikasi, Klasifikasi, dan Interpretasi Tanda Scene 3}

Perdebatan mereka antara polisi dengan pelanggar, seharusnya pelanggar bisa menghormati dan menyadari pelanggarannya. Namun dengan pesan postural berupa power, pelanggar terlihat ingin mengungkapkan status yang lebih tinggi pada polisi dengan menyatakan bahwa dirinya memang tidak bersalah dan mengatakan bahwa pekerjaan polisi hanya bisa menilang saja seolah memang polisi tidak memiliki pekerjaan lain selain menilang dan meminta uang pada para pelanggar. "Yaelah pak, saya kan cuma bentar pak, saya helm pake, surat-surat lengkap, pentil ada, masa gini aja ditilang sih pak.... bilang aja butuh duit kan? Heran! Polisi kerjaannya nilang doing ya?!". 

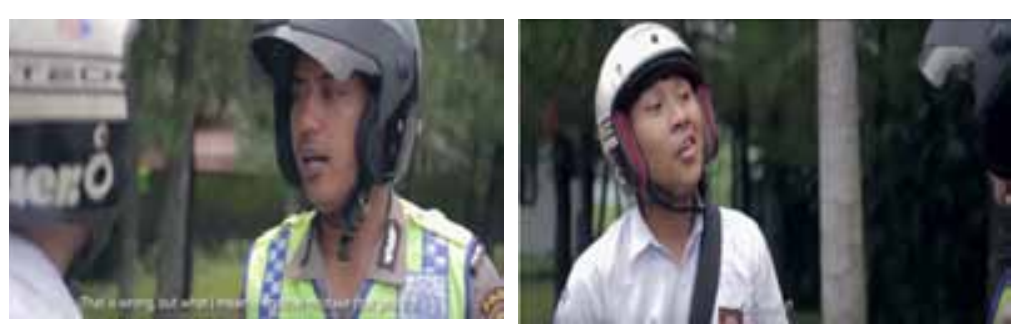

Gambar 4. Scene 3

(Sumber: www.youtube.com)

Namun dengan raut wajah dan gerakan tubuh pelanggar yang tidak sopan dan tidak menghormati profesi polisi, sama sekali tidak membuat polisi marah ataupun menunjukkan wajah kesal. Justru sebaliknya, polisi menunjukkan pesan fasial penuh kesabaran yang ditunjukkan dengan senyuman tulus dan helaan nafas yang cukup panjang sambil mengatakan:

"Gini mas, mas kan ga pernah jadi polisi, tugas polisi tuh ga cuma nilang doang, masih banyak pekerjaan polisi yang lain, jadi jangan sembarangan berkomentar!"

Pesan fasial polisi dalam menghadapi pelanggar tersebut memberikan makna bahwa tugas seorang polisi tidak hanya sekedar menilang dan memberikan sanksi tegas, namun juga berusaha memberikan pengertian dengan tegas dan sabar bahwa tugas seorang polisi tidak hanya sekedar menilang apalagi meminta uang pada para pelanggar. Pesan nonverbal yang ditampilkan melalui wajahnya, mengkomunikasikan tingkat pengendalian seorang polisi terhadap pernyataan pelanggar yang sebenarnya membuat ia kesal, namun karena ia harus profesional, ia menanggapinya tetap dengan senyuman. Selain itu, pengambilan wajah polisi saat menunjukkan pesan fasial berupa senyuman tulus dengan teknik zoom in (memperbesar tampilan obyek pada kamera dengan cara mendekatkan lensa) menunjukkan penekanan tokoh polisi sesungguhnya yang ingin ditampilkan pada publik. Seolah semua sosok polisi memang tegas, ramah, dan tulus tanpa ada kekurangan.

\section{Identifikasi, Klasifikasi, dan Interpretasi Tanda Scene 4}

Tanda yang muncul pada capture gambar pertama (kiri) memperkuat sosok anak SMA bernama Joni yang semakin tidak sopan pada polisi. Tanda yang ditunjukkan di atas menggambarkan
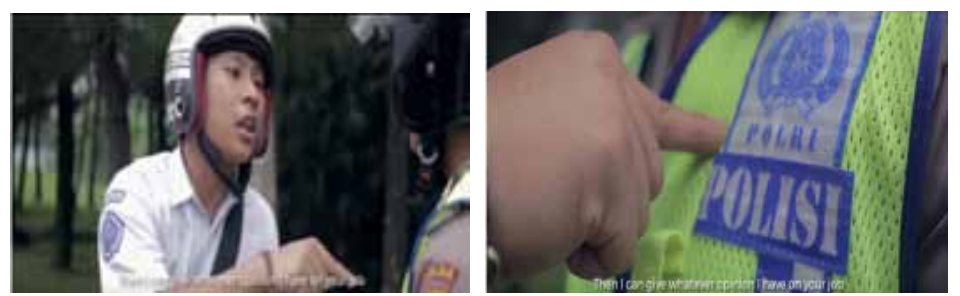

Gambar 5. Scene 4

(Sumber: www.youtube.com)

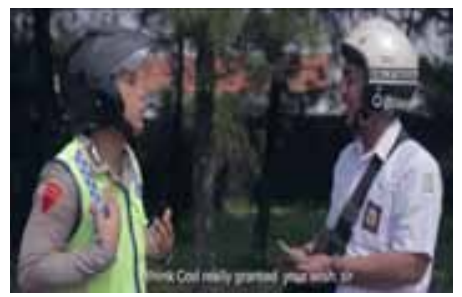


negatif. Pesan responsive negatif ditunjukkan pada gambar ketiga, dimana seluruh gerakan badan pelanggar merasa tidak terima dengan berubah dirinya menjadi seorang polisi, sedangkan pesan responsive positif dapat dillihat pada sekuruh gerakan badan polisi yang merasa senang karena pelanggar berubah menjadi polisi, artinya tugas ia sebagai polisi akan dialihkan pada pelanggar.

Bila diperhatikan, pertukaran peran hanya ditunjukkan dengan pertukaran seragam dan atribut antara polisi dan anak SMA, sedangkan karakter, gerak-gerik, dan tingkah lakunya tidak ada yang berubah. Proses pertukaran peran yang ditunjukkan dengan pertukaran seragam beserta atributnya tersebut menjadi tanda yang menginterpretasikan bahwa kita tidak bisa menilai buruknya suatu profesi hanya karena penilaian generasilasi yang diberikan oleh masyarakat selama ini. Buktinya, saat terjadi pertukaran peran dalam sekejap, ia (Joni) tidak bisa melakukan perannya sebagai seorang polisi meskipun ia sudah memakai seragam dan atribut polisi.

\section{Identifikasi, Klasifikasi, dan Interpretasi Tanda Scene 5}

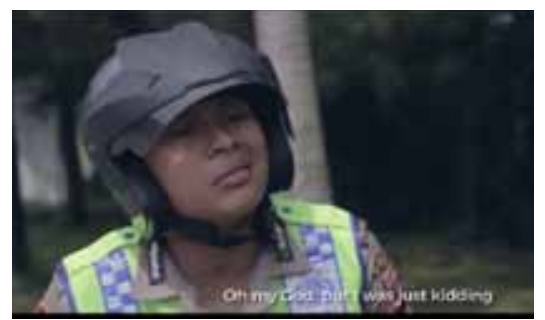

Gambar 6. Scene 5

(Sumber: www.youtube.com)

Pada scene kelima, makna tanda non verbal yang ditunjukkan adalah pesan kinesik berupa pesan fasial yang mengkomunikasikan tingkat pengendalian individu terhadap pernyataan sendiri.
Saat pelanggar berubah menjadi sosok polisi, dapat dilihat ia tidak dapat mengendalikan dirinya atas penyataannya sendiri yang mengungkapkan kalimat doa "Saya doain sama Allah semoga bisa jadi polisi, biar bisa ngomentarin kerjaan bapak (sambil menunjuk dada kiri polisi)". Ketidakmampuan pengendalian individu terhadap pernyataannya sendiri juga dilihat dari ungkapan verbal "Saya cuman bercanda Ya Allah, kok jadi beneran" dan raut wajah memelas agar bisa kembali menjadi anak SMA. Wajah memelas atau memohon ini menunjukkan kesadaran bahwa memang pekerjaan polisi tidak mudah dan belum tentu semua orang berani dan bisa menjalani profesi sebagai polisi.

\section{Identifikasi, Klasifikasi, dan Interpretasi Tanda Scene 6}
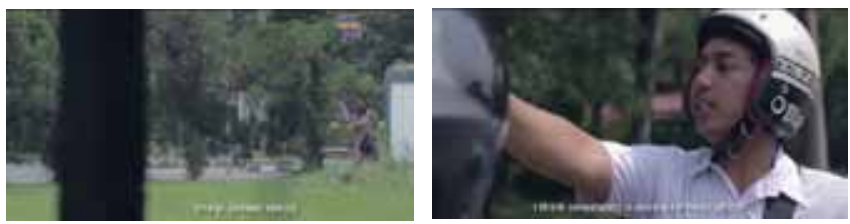

Gambar 7. Scene 6

(Sumber: www.youtube.com)

Pada scene keenam, tanda yang terdapat dalam dua scene tersebut ingin menunjukkan bahwa meskipun polisi sudah berubah wujud menjadi anak SMA secara atribut, namun kepekaannya terhadap tindak kejahatan tetap tajam. Bila dilihat pada gambar kiri, terlihat seorang wanita teriak meminta tolong karena barangnya dicuri, dan di gambar kanan terlihat polisi yang sudah berubah wujud menjadi anak SMA tetap responsif terhadap tindak kriminal tersebut, sedangkan anak SMA yang sudah berubah wujud menjadi polisi justru baru sadar setelah diberitahu oleh polisi yang berubah menjadi anak SMA tersebut.
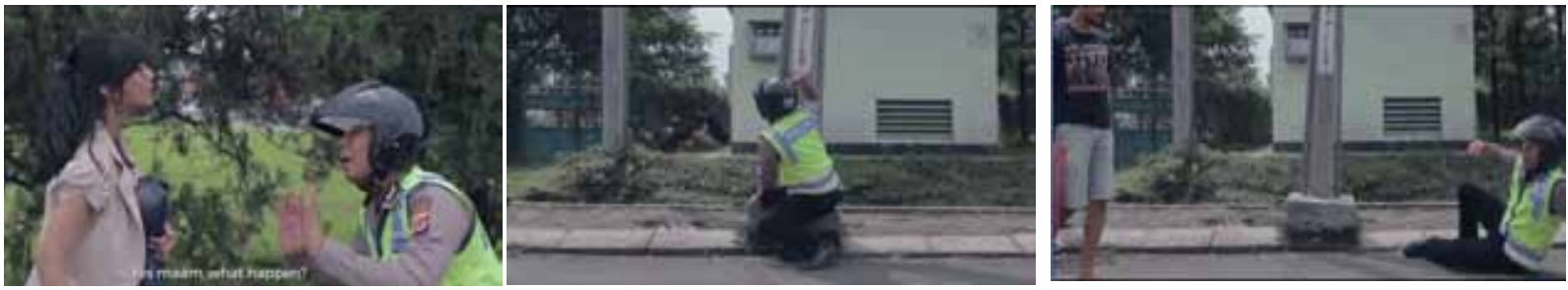

Gambar 8. Adegan Polisi saat takut menangkap penjahat

(Sumber: www.youtube.com) 
Dikarenakan anak SMA sudah berubah wujud menjadi polisi, maka mau tidak mau yang menolong wanita tersebut adalah dirinya. Dengan penuh rasa tidak percaya diri di wajah dan gerakan tubuhnya, akhirnya ia berusaha menangkap penjahat tersebut dengan cara melempar batu kecil ke badan penjahat (lihat gambar tujuh tengah). Pelemparan batu kecil tidak sejalan dengan tindakan polisi pada umumnya dimana polisi pada umumnya mengeluarkan pistol agar penjahat memiliki rasa takut dan akhirnya menyerahkan diri pada polisi. Schoolpouringrights.com mengungkapkan bahwa pistol merupakan senjata yang sangat mematikan dan sering digunakan oleh para polisi di berbagai belahan dunia untuk melumpuhkan maupun membunuh para penjahat. Namun hal itu tidak terjadi pada anak SMA yang berubah menjadi polisi, justru bila dilihat pada gambar tujuh (kiri), pesan postural berupa pesan power pada polisi sama sekali tidak terlihat. Pesan power pada kedua penjahat justru lebih kuat dibandingkan dengan polisi itu sendiri.

Secara keseluruhan, pada scene ini ingin menampilkan bahwa tugas seorang polisi selain memberikan peringatan, meminta identitas diri dan kendaraan, dan menilang, juga tugas lainnya adalah harus peka terhadap segala tindak kejahatan termasuk kasus pencurian yang terjadi dalam adegan tersebut. Namun tidak hanya berhenti sampai di situ, polisi asli yang telah berwujud menjadi anak SMA ternyata tidak tinggal diam melihat Joni hampir kalah karena tidak memiliki kemampuan bela diri. Polisi asli yang tengah menggunakan seragam putih abu tersebut langsung membantu menghadang dan akhirnya menangkap para penjahat.
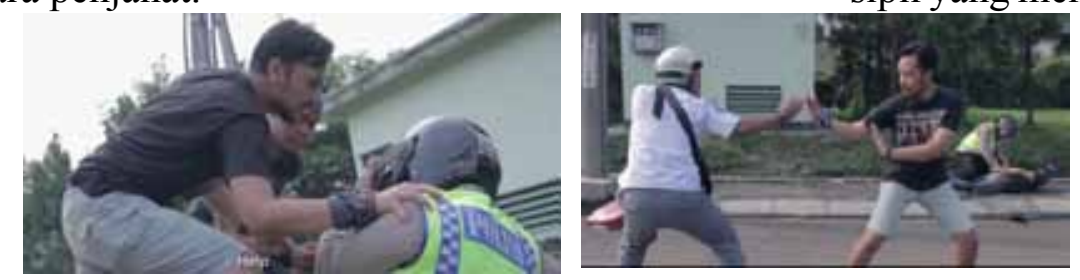

Gambar 9. Adegan Melawan Penjahat

(Sumber: www.youtube.com) kejahatan. Buktinya mesikpun polisi asli di awal sudah diremehkan bahwa pekerjaannya hanya menilang saja, namun ia tetap membantu Joni saat ia haru melawan dua penjahat sekaligus. Hal ini juga diperkuat oleh pertanyaan verbal oleh polisi, "Gimana mas masih pengen jadi polisi?" lalu Joni sebagai anak SMA yang menantang dan akhirnya berubah menjadi polisi dengan yakinnya menjawab "Haduh, kayanya engga deh pak, ternyata jadi polisi susah juga yah pak, kirain kerjaannya nilang doang pak".

\section{SIMPULAN}

Setiap bagian yang peneliti kaji dan tuangkan pada bagian hasil penelitian di atas, merupakan tanda-tanda yang muncul pada film pendek berjudul "Joni Sok Jagoan". Peneliti menyimpulkan bahwa pembuat film pendek tersebut berusaha menyampaikan pesan dengan konsep film yang disesuaikan dengan fenomena dan selera anak muda saat ini, dimana pengemasan jalan cerita yang disajikan membuat penontoh terhibur, namun pesannya tetap bisa dipahami dengan baik.

Adapun kesimpulan berkaitan dengan citra polisi dalam film pendek ini cukup tersampaikan, karena masyarakat khususnya anak muda selama ini menganggap bahwa tugas polisi hanya bisa menilang dan meminta uang. Apa yang masyarakat pikirkan selama ini tentu sangat mempengaruhi citra kepolisian dalam ranah negatif. Namun, film pendek tersebut berhasil membangun citra positif polisi kembali, dimana polisi ditampilkan sebagai sosok pahlawan dengan beragam macam tugas yang harus tetap rendah hati dalam menghadapi beragam sikap para pelanggar maupun msyarakat sipil yang membutuhkan bantuan. Citra positif juga

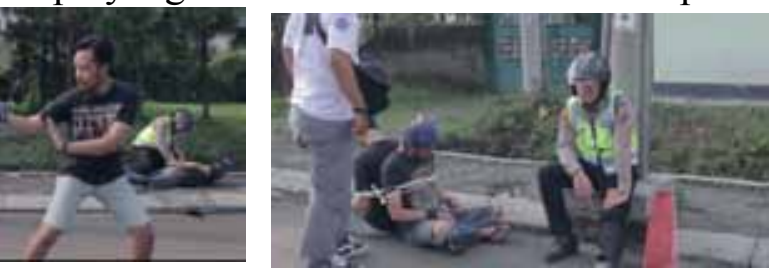

terlihat dari sikap tanggap untuk menolong orang lain meskipun orang tersebut sudah merendahkan profesinya. Melalui film pendek dan analisis semiotika citra polisi dalam fim Joni Sok Jagoan ini tentu diharapkan agar masyarakat luas bisa 
merubah pemikirannya yang negatif terhadap citra Kepolisian Republik Indonesia.

Peneliti menilai bahwa Sebelas Sinema Pictures telah mampu menciptakan konsep film pendek yang menarik dalam menyampaikan pesan moral kepada masyarakat dengan sajian yang cukup menghibur. Selanjutnya, Sebelas Sinema Pictures maupun pihak Police Movie Festival diharapkan tidak melupakan tujuan utama dari penyampaian pesan melalui film pendek yaitu agar masyarakat tidak salah dalam menilai kepolisian RI bahwa polisi bukan sekedar profesi, melainkan jalan untuk mengabdi. Perjuangannya dalam mendedikasikan diri serta loyalitas selalu diberikan bukan untuk kepentingan pribadi tetapi untuk kepentingan orang lain. Pengorbanan atas waktu, tenaga dan pikiran mereka tetap tercurahkan untuk menyelesaikan permasalahan masyarakat yang semakin rumit dan pelik.

\section{DAFTAR PUSTAKA}

Barnard, M. 2006. Fashion sebagai Komunikasi Cara Mengomunikasikan Identitas Sosial, Seksual, Kelas, dan Gender). Yogyakarta: Jalasutra.

Berger, A. A. 2000. Media Analysis Techniques (Second Edition). Yogyakarta: Penerbitan Universitas Atma Jaya.

Bonafix, D. Nunnun. 2011. Videografi: Kamera Dan Teknik Pengambilan Gambar. Jurnal Binus University Vol. 2 (1), 845-854.

Devito, J. A. 2011. Komunikasi Antarmanusia (Edisi Kelima). Tangerang: Karisma Publishing Group.

Gatra, Sandro. 2017. Survei "Kompas": Polri Semakin Diapresiasi Publik. Retrieved 14 February 14 2018, from www.nasional. kompas.com/read/2017/07/03/10403051/ survei.kompas.polri.semakin.diapresiasi. publik

Herwendo, R. 2014. Analisis Semiotika

Representasi Perilaku Masyarakat Jawa. Jurnal Wacana Vol. XIII (3), 230-245.

Hudzaifah, Suwachid, dan Emilly Dardi. 2013. Analisis Pemakaian Seragam Sekolah Siswa Smk Dalam Tinjauan Pendidikan Kritis Di Smk N 5 Surakarta Tahun Ajaran
2011/2012. Retrieved 30 June 2018, from www.download.portalgaruda.org/article. php? article $=109528 \&$ val $=4092$

Kepolisian Negara Republik Indonesia. Polri go.id/ tentang-tilang.php. Retrieved 14 February 2018, from www.polri.go.id/tentang-tilang. php

Kholifah, S. 2014. Analisis Semiotika Pesan Sosial Dalam Video "Takotak Miskumis" Di Youtube. eJournal Llmu Komunikasi, 2(3), 135-149.

Kriyantono, R. 2009. Teknik Praktis Riset Komunikasi. Jakarta: Kencana Prenada Media Group.

Littlejohn, S. W. 1996. Theories of Human Communications (Fifth Edit). New York: Wadsworth Publishing Company.

Mulyana, D. 2008. Ilmu Komunikasi Suatu Pengantar. Bandung: PT Remaja Rosdakarya.

Police Movie Festival. 2016. Lomba Film Pendek Police Movie Festival 32016. Retrieved 14 February 14 2018, from www.festivalkreatif.com/police-moviefestival-3-2/.

Rahmat, J. 2011. Psikologi Komunikasi. Bandung: PT. Remaja Rosdakarya.

Ruliana, P. 2014. Komunikasi Organisasi: Teori dan Studi Kasus. Depok: PT Rajagrafindo Persada.

School, I. D. 2014. Pengertian Film Pendek Fiksi Naratif. Retrieved 14 February 2018, from www.idseducation.com/articles/ pengertian-film-pendek-fiksi-naratif/

Schoolpouringrights.com. 2018. Sejarah Perkembangan Dan Jenis Pistol. Retrieved 30 June 2018, from http:// www.schoolpouringrights.com/teknologi/ sejarah-perkembangan-dan-jenis-pistol/

Sobur, A. 2009. Semiotika Komunikasi. Bandung: PT Remaja Rosdakarya.

Sofwan, R. 2016. Tito Fokus Perbaiki Citra Kepolisian di Masyarakat. Retrieved 14 February 2018, from https://www.cnnindonesia.com/ nasional/20161011182345-12-164821/ 
tito-fokus-perbaiki-citra-kepolisian-dimasyarakat

Stephen W. Littlejohn., \& K. A. F. (2014). Teori

Komunikasi (Edisi 9). Jakarta: Salemba Humanika.

Sutrisno. 2016. Sosiologi Kepolisian, Relasi Kuasa Polisi dengan Organisasi Masyarakat Sipil Pasca Orde Baru. Jakarta: Yayasan Pustaka Obor Indonesia.

Tashandra, N. 2016. Faktor yang Membuat Kepercayaan Publik Rendah terhadap Polisi Versi Jenderal Tito. Retrieved 14
February 2018, from http://nasional. kompas.com/ read/2016/08/18/18524141/ faktor.yang.membuat.kepercayaan.publik. rendah.terhadap.polisi.versi.jenderal.tito

Tempo.co. 2016. Joni Sok Jagoan Borong Piala Lomba Film tentang Polisi. Retrieved 14 February 2018, from www.seleb.tempo. co/read/781346/joni-sok-jagoan-borongpiala-lomba-film-tentang-polisi

Vera, N. 2015. Semiotika dalam Riset Komunikasi. Bogor: Penerbit Ghalia Indonesia. 